\title{
The Role of Political Institutions in Africa In Building Democratic Governments
}

\author{
Idris Mahmoud Idris \\ Department of Political Science, International Islamic University \\ Malaysia (IIUM) \\ ihasaballah11@gmail.com \\ Elfatih Abdullahi Abdelsalam \\ Department of Political Seinci, International Islamic University Malaysia \\ (IIUM) \\ elfatih@iium.edu.my \\ Abdulhamid Mohamed Ali Zaroum \\ International Islamic University Malaysia (IIUM) \\ alzaroumi@iium.edu.my
}

\begin{abstract}
The "third wave" of democratization, which saw the fall of old authoritarian regimes across Africa, as well as the introduction of multiparty elections and other significant new changes, has faded. Today, we are witnessing a reversal of democratic gains in favour of dictatorship, resulting in political instability and severe outbreaks of violence in Ethiopia, Mozambique, Kenya, the Ivory Coast, Nigeria, and elsewhere. This article seeks explanation for the failures of the democratization process in Africa, focusing on the challenging role of political institutions in determining the nature of transition trajectories, reviewing its significance, and justifying why this factor is important when analyzing the success or failure of democratization. The paper sought to provide a more robust understanding of Africa's democratization failure and the thorny issue of a transitional path toward good governance. The study found that the progress of the democratic transition process at any given point in history is dependent on the existence of powerful and capable political institutions equipped to face and respond to the challenges of the transition process, and that the more integrated and independent government and civil society institutions are, the more likely democratic practices will thrive. Furthermore, the study showed that under authoritarianism, institutions like elections, political parties, and legislatures are often referred to as "pseudo-democratic" because they are copied, imitated, and mocked to manipulate the concept of democracy and serve the continuation of autocratic rule.
\end{abstract}

Keywords: Democratization; Africa; Political Institutions; Authoritarianism. 


\section{The Role of Political Institutions in Africa In Building Democratic Govern- ments}

\section{Introduction}

A number of African countries have gone through democratization since the 1980s. The Third Wave of Democratization (Huntington, 1991), however, did not result in building democratic governments. Newly established democratic institutions have frequently failed to resolve conflicts among key political organizations, some governments have deviate from democratic institutions leaving political power remains highly personalized, and in some cases, democratic institutions gradually deteriorated, allowing authoritarian regimes to resurface. This paper aims to analyse the role of political institutions in Africa in building democratic governments, and it relies on qualitative approach to gather data from secondary sources. This study's problem is based on the undeniable fact that political institutions are critical for constraining actors' actions and choices, outlining deliberations, aggregating preferences into collective decisions, and enforcing decisions. As a result, the study contends that the progress of the democratic transition process at any given point in history is dependent on the existence of strong political institutions capable of confronting and responding to the transition process's challenges. The more integrated and independent government and civil society institutions are, the greater the likelihood of democratic practices prospering. Under authoritarianism, institutions such as elections, political parties, and legislatures are often referred to as "pseudo-democratic" because they are copied, imitated, and mocked to manipulate the concept of democracy and serve the continuation of autocratic rule. Whereas powerful and independent institutions empowers the people to hold their elected officials accountable, using the power of the ballot to restrain the greedy political office holders who use their position of power for personal gain and force them to work for the interests of their constituencies while inspiring them to transform their political behavior and be more conscious of who they are and what they are to the society (Adetiba, 2018). That is why it is often said that "If political institutions are the 'hardware' of a democratic system, what people think about democracy and those institutions constitute the 'software' of that system. And as all systems designers know, hardware is just as important as software (Khabele, 2017)"

The renaissance of scholarship concerning political institutions' role in shaping political processes and outcomes has been an important focus of recent research (Wright, 2015). Extensive research has been conducted to understand and explain the processes and dynamics that have led 
Idris Mahmoud Idris, Elfatih Abdullahi Abdelsalam, Abdulhamid Mohamed 438

Ali Zaroum

to the failure of African countries to build democratic governments. General theories, concepts, approaches, and comparative analysis studies were developed to address the issue. Works by Samuel Decalo, Richard Joseph, Nicolas van de Walle, Amundsen, Chabal Staffan Lindberg, and others address a variety of critical factors that have contributed to the failure of democratic governments to emerge. Many relevant studies focus on the state of the economy, the significance of street protests, the influence of moderates, and international pressure on African governments (Richard, 1997). This study focuses on the most common approaches to the issue of democratic transition in Africa and addresses the critical role of political institutions, and constitutionalism, which some scholars consider to be the main factor of democratization success or failure. Theoretically, in order to explain the success and failure of democratic transition in Africa, numerous studies have focused on economic conditions, political culture and international factors, however, recent research studies have shown that these factors do not convincingly account for transition trajectories; it has been found that economic condition and the international factor prove somewhat helpful, but the most compelling explanation, however, centers on political and institutional legacies (Dahl, 1989). Therefore, recently there has been a considerable shift from structural determinants to strategic choices in the explanations of democratic transition. And the debate on the meaning of democracy has shifted essentially from its substance-its source and purpose-to its procedures. Procedural democracy which concerns the selection of leaders through competitive elections by the people (Schumpeter, 1943) become the prevailing school of thought in modem times and has been accepted by scholars widely and in a large scale. The development of this concept is due to the contributions of pioneers such as Joseph Schumpeter, William Riker, and Russell Hardin, among others. Schumpeter defines democracy as the "institutional arrangement for arriving at political decisions in which individuals acquire the power to decide by means of a competitive struggle for the people's vote" (Schumpeter, 1943) Here Schumpeter presents democracy as a political method (Schumpeter, 1943), he sought to develop an empirically based model of democracy in which the people themselves decide on political issues by electing representatives who carry out the people's will. He insists that democracy as a method is only instrumentally valued, i.e., a certain type of institutional arrangement for arriving at political legislative and administrative decisions (Schumpeter, 1943). The strength of this framework stems from its emphasis on procedures, because democracy does not happen overnight, 


\section{The Role of Political Institutions in Africa In Building Democratic Govern- ments}

and on institutionalism, because democracy cannot be consolidated without strong political institutions.

Douglas North defines institutions as: "The humanly devised constraints that structure human interaction. They are made up of formal constraints (rules, laws, constitutions), informal constraints (norms of behavior, conventions, and self-imposed codes of conduct), and their enforcement characteristics. Together they define the incentive structure of societies and specifically economies (North, 1994)." Hence, political institutions are the organizations ${ }^{1}$ in a government which create, enforce, and apply laws. They often mediate conflict, make (governmental) policy on the economy and social systems, and otherwise provide representation for the population. The primary purpose of state institutions is to provide government authority and thereby enable it to govern. For instance, the formal institutions of government, such as legislature, executive and judiciary, give the subject matter of comparison in terms of their powers, functions, roles and mutual relations. It argues that the success of political transformation depends on setting up institutions that can deal adequately with new challenges created such as social, economic, and political challenges and their enforcement features. Furthermore, democratic institutions include political party organizations, military organizations, civil society, electoral systems, constitution, the media, trade unions, legal courts, human rights legislation, etc. They include bundles of citizenship-related rights and obligations, methods of organizing interests, electoral system, arrangements of dividing, supervising powers, and so on (Przeworski, et al. 1995). However, those relating to the type of executive, legislature, political parties, constitution and electoral system are the key institutions that have gained an increasing amount of popularity in comparison to the rest.

\footnotetext{
${ }^{1}$ The terms organization and institution are often used interchangeably. Organization refers to an organized group of people gathered together to achieve a particular purpose. At the same time, the institution can be applied to both a type of formal organization, practices, and society pattern. Similarly, the distinction between formal and informal institutions is 'fuzzy' We refer to formal institutions as the rules that govern the different organizational components of political life, such as political parties, bureaucracies, electoral processes, the branches of government (executive, legislative and judiciary), constitutions, trades unions, business groups, and civil society organisations, notes that the list is extendable. Informal institutions are more ambiguous but can define it as institutional that exclusively reliant on unwritten rules in use.
} 
Idris Mahmoud Idris, Elfatih Abdullahi Abdelsalam, Abdulhamid Mohamed 440

Ali Zaroum

This is particularly reflected in the choice of executive structure (presidential, semi-presidential or parliamentary), of legislature (single or double chamber), of political parties (adversarial or consociational, and their sufficient number in parliament) and of electoral system (majoritarian, mixed or proportional) (Sartori, 1994). The most important democratic institutions, as per Robert Dahl, are elected officials; free, fair and frequent elections; freedom of expression; access to alternative sources of information; and associational autonomy and inclusive citizenship (Dahl, 1998).

Institutionalism is a state apparatus based on bureaucracy, characterized by rationality and legitimacy, supported by civil society, monopolized by the use of force, and dominated by economic and political communities. It is represented in the separation of powers, the existence of state law, the subordination of rulers to the law, and the organization of legislative and judicial control over the ruling authorities. Przeworski claims that "The central distinctive task of democratic institutions is to limit power monopoly (Przeworski, et al. 1995)." Therefore, democratic institutions should be evaluated based on electoral data, party competition, and the performance and accomplishments of political institutions that display the state wherever it is more or less democratic.

\section{The state of democratization in Africa}

By mid-1960s, most of the African countries were liberated, and the post-colonial "nation-building" project begun. Ironically, however, procedural and institutional approach to democracy which embedded pluralists was rejected as a colonial legacy (Peter, 1987). Instead, one-party rule was introduced throughout the continent, becoming the ideology of national unity and rapid economic development. In this period, one-party rule was romanticized and marketed to the masses by the new leaders to sustain themselves in power. The outcome was a multi-dimensional political, economic and socio-cultural crisis with far-reaching implications.

Since the late 1980s and early 1990s, a new dispensation has arisen in the context of the post-Cold War. The revolutionary changes in Eastern Europe, the fall of apartheid in South Africa had generated political waves that initially seemed to have ended the era of authoritarianism in Africa in a time in which the continent's most brutal dictators like Mobutu of Zaire, 


\section{The Role of Political Institutions in Africa In Building Democratic Govern- ments}

Said Barre of Somalia, and Mengistu of Ethiopia and others, were removed from power.

Today, however, democratization in Africa remains a mixed bag. Some countries have not yet undergone the transition to democracy. Others have succeeded in transitioning from one-party, one-person, or military regimes to multi-party democracies. Many others are showing signs of reversal of democratic gains in favor of dictatorship causing political instability, severe outbreaks of violence, as seen in Ethiopia, Mozambique, Kenya, the Ivory Coast and Nigeria.

In its 2021 report Freedom House ${ }^{2}$ rated only eight countries in subSaharan Africa as free. Half of these eight are small island nations, including Mauritius, Cape Verde, Sao Tome and Principe, and Seychelles. Others are Botswana, South African, Namibia and Ghana. In contrast, according to the BTI 2020 report, ${ }^{3}$ in the sub-Saharan Africa countries considered to be consolidating ( 2 countries), defective democracies (13), highly defective democracies (7), moderate autocracies (9) and hard-line autocracies (13).

Table 1.1 shows the ranking of Sub-Saharan Africa's democracy index scores, as determined by BTI 2020 index. The general pattern has been for the continent's more authoritarian states - 13 countries out of 44 ranked as hard-line autocracies - despite the fact that Africa has seen a number of changes in leadership that have generated hope for political renewal and economic reform. This includes Angola, South Africa, Ethiopia, Sudan, Zimbabwe, Sierra Leone, and Nigeria, where power transfers were accompanied by promises of significant differences for democratic norms and values. However, events since 2019 have cast doubt on the significance of these transitions. Most notably, power has been personalized, and, in some cases, increasing human rights violations in countries such as Ethiopia, Sudan, Nigeria, Tanzania, and Zimbabwe suggest that we have seen "a changing of the guards" but not a change of political systems (Cheeseman, 2020). Africa's leadership transitions sparked initial optimism, but ongoing political challenges and constraints necessarily imply

\footnotetext{
${ }^{2}$ https://freedomhouse.org/countries/freedom-world/scores

${ }^{3}$ Bertelsmann Transformation Index (BTI) https://atlas.bti-project.org/share.php? $1 * 2020 * \mathrm{GV}:$ SIX:0*CAT*ANA:REGION
} 
Idris Mahmoud Idris, Elfatih Abdullahi Abdelsalam, Abdulhamid Mohamed 442 Ali Zaroum

that the more things change, the more they stay the same, owing to a lack of more powerful and independent democratic institutions. Indeed, for Africa to progress on its path to democratization, peace building, and development, it needs strong institutions rather than strong men.

Tab. 1: Status of political transformation in sub-Saharan Africa 2020

\begin{tabular}{|c|c|c|c|c|}
\hline $\begin{array}{l}\text { Consolidating } \\
\text { democracies }\end{array}$ & \begin{tabular}{|l}
$\begin{array}{l}\text { Defective de- } \\
\text { mocracies }\end{array}$ \\
\end{tabular} & $\begin{array}{l}\text { Highly defective } \\
\text { democracies }\end{array}$ & $\begin{array}{l}\text { Moderate au- } \\
\text { tocracies }\end{array}$ & $\begin{array}{l}\text { Hard-line autocra- } \\
\text { cies }\end{array}$ \\
\hline Scores 10 to 8 & Scores $<8$ to 6 & Scores $<6$ & Scores $>4$ & Scores $<4$ \\
\hline $\begin{array}{l}\text { Mauritius } \\
\text { Botswana }\end{array}$ & $\begin{array}{l}\text { Ghana } \\
\text { Benin } \\
\text { Namibia } \\
\text { South Africa } \\
\text { Senegal } \\
\text { Gambia* } \\
\text { Liberia } \\
\text { Malawi } \\
\text { Guinea-Bissau* } \\
\text { Sierra Leone* } \\
\text { Burkina Faso } \\
\text { Niger } \\
\text { Tanzania }\end{array}$ & $\begin{array}{l}\text { Guinea } \nabla \\
\text { Côte d'Ivoire } \\
\text { Mali } \\
\text { Zambia } \nabla \\
\text { Lesotho } \\
\text { Nigeria } \\
\text { Madagascar }\end{array}$ & \begin{tabular}{|l} 
Uganda \\
Togo \\
Kenya $\nabla \nabla$ \\
Gabon* \\
Angola \\
Mozambique \\
Zimbabwe $\Delta$ \\
Mauritania \\
Ethiopia $\Delta$
\end{tabular} & $\begin{array}{l}\text { Rwanda } \\
\text { Djibouti } \\
\text { Burundi } \\
\text { Eswatini } \\
\text { Cameroon } \\
\text { Central African • } \\
\text { Congo, DR • } \\
\text { Congo, Rep. } \\
\text { Chad } \\
\text { Equatorial Guinea } \\
\text { South Sudan • } \\
\text { Eritrea } \\
\text { Somalia } \bullet\end{array}$ \\
\hline
\end{tabular}

Sources: Cheeseman, N. (2020) A Changing of the Guards or A Change of Systems? BTI Regional Report Sub-Saharan Africa 


\section{The Role of Political Institutions in Africa In Building Democratic Govern- ments}

Why did many African countries attempts at democratization fail?

According to several analysts of political developments in Africa, ${ }^{4}$ the critical challenges to the transition to democracy in sub-Saharan Africa in the 1980s and 1990s were: legacy of brutality, the absence of a functioning legal system, institutional disarray and periodic eruption of conflict.

Decalo Samuel attributed the failure of democratic transformation to the lack of most, if not all, factors that were generally considered to be conducive to democratization (Decalo, 1992)" others attributed it to the neopatrimonial rule, personal rule, and state-based clientelism (Tripp, 2001) Cheeseman singles out three fundamental obstacles of democracy in Africa. They are the rise of neopatrimonialism, the establishment of centralized state structures that have absolute control over economic opportunities and the legacy of the colonial past (Cheeseman, 2015). According to Earl Conteh-Morgan, there have been deadlocks, reverses, failures, and mounting complexities in a number of counties, mainly because some of the third world political actors (incumbent regime, the military, the ruling party or main political opposition) do not want to lose in the power-political struggles (Conteh-Morgan, 1997). Yet recent writings on post-liberation politics (Melber 2002), drawing mainly on the experiences of Zimbabwe, Namibia, Uganda, Eritrea and South Sudan, have highlighted the influence of the liberation war and anti-colonial liberation movements' who assume power and reorganize themselves as political parties of the state apparatus.

Overall, several factors, considerations, and causes have been proposed in the literature to explain why many African countries' attempts at democratization have failed. Economic underdevelopment, poverty, illiteracy, and the nature of political institutions, ${ }^{5}$ as well as a lack of civil

\footnotetext{
${ }^{4}$ Several works are focusing on various dimensions of the failure of democracy in Africa. Among them are: Earl Conteh-Morgan, democratization in Africa (1997); Bratton, M. \& van de Walle, Democratic Experiments in Africa (1997); Robert Pinkney, Democracy in the third world (1994); Georg Sorensen, Democracy and democratization (1993); Constantine P. Danopoulous (ed.) Civilian Rule in the developing world (1992)

${ }^{5}$ Scholars and policymakers have widely documented institutional weakness as a significant problem in Sub-Saharan Africa.
} 
Idris Mahmoud Idris, Elfatih Abdullahi Abdelsalam, Abdulhamid Mohamed 444

Ali Zaroum

society, militarization, external interventions, and low levels of industrialization to name a few, were proposed.

It is critical to stress the significance of political institutions in understanding why democratization projects frequently fail. It is an important factor in determining the outcome of the political transition. Democratization in Africa is not about waiting for a certain level of prosperity or the right historical moment, but about respecting institutions and implementing the constitution with a new type of political leader. It is a critical mechanism for engaging communities and ensuring more transparent governance. In the absence of institutions, an increasing number of people are being excluded from the political process, as the rule of law is eroded and opportunities for political participation are reduced. In addition, more people are being excluded from economic participation, subjected to unfair competition, and social inequality is growing. The unwillingness to build a strong state in the absence of a liberal society, as well as the continued reliance on strong men, hampered the development of a framework of democratic regulation. Hence, one could argue that the role of political institutions explains a very complex process because it connects too many variables that influence the democratization process. It has also had a significant impact on the transition process's success or failure. In this article, we will look at the role of political institutions as the most noticeable factor across the African continent, to provide an answer to the question posed here.

\section{The role of political institutions}

Political institutions play an important role in shaping political processes and increasing the chances of a democratic transition; thus, the success of a country's democratic system is dependent on the existence of state institutions that allow citizens to participate widely in politics. The institutional analysis offers a more compelling and comprehensive explanation of Africa's democratic transition. Because political institutions have a significant impact on the formation of policies and patterns of political action, as well as the objectives and preferences of political actors, it identifies the critical structural condition under which democratic transitions occur. 


\section{The Role of Political Institutions in Africa In Building Democratic Govern- ments}

\section{Essential conditions for democratic institutions to play their role}

In this context Robert Dahl placed a number of necessary conditions for democratic institutions to play their role, the most important among them are: 1- Control over military and police by elected officials 2Democratic beliefs and political culture 3- Absence of influential foreign control hostile to democracy. He also added that these institutions must work within the framework of a democratic society characterized by the modern market economy and society, with cultural conflicts weak or absent to develop and maintain democratic political institutions (Dahl, 1998). Dahl points out that the absence of one or more of these conditions do not make democracy impossible. In this context, Dahl refers to the complex model of the Indian democracy, which lacks some of these conditions, but nevertheless enjoys a stable democratic order (Dahl, 1998).

\section{Political Institutions and the processes of democratization}

When explaining the failure of the transition to a democratic system, do political institutions matter? The literature on democratic transitions has typically concentrated on institutional factors such as political processes and actors' choices in explaining regime change (O'Donnell \& Schmitter 1986; Di Palma 1990; Przeworski 1991; Karl 1991; Mainwaring (et al) 1992).

Today, there is no controversy about the importance of institutions in the stage of democratization and democratic consolidation. Various scholars have emphasized this issue, including Samuel Huntington's seminal and Francis Fukuyama's (Fukuyama, 2011; Farrar and Fukuyama, 2014). Both Huntington and Fukuyama agree that the absence of effective and robust political institutions in some countries undermines political order, resulting in democratic governance failure and political decay. Huntington wrote one of the most important researches on democratic institutions and democracy - Political order in evolving societies". He argued in the analysis of how to defend and promote democracy, that one of the dysfunctional factors in society was inadequate institutionalization. he further stated, "the primary problem of politics is the lag in the development of political institutions behind social and economic change (Huntington 1968)." In their book entitled Why National Fail: The Origins of Power, 
Idris Mahmoud Idris, Elfatih Abdullahi Abdelsalam, Abdulhamid Mohamed 446

Ali Zaroum

Prosperity and Poverty, co-authored by Daron Acemoglu and James Robinson; They have found that many factors explain failure or success of nations world-wide, central among which are institutions, leadership, and peace (Acemoglu and Robinson 2012).

Democratic institutions are, therefore, an important part of the democratic transformation and a precondition for its success since they ensure that the system works in compliance with the law and not, in particular, with the rulers' whims. Africa needs strong institutions and not strong men in order to progress on its path towards democratization, development and peace building. Institutions must clearly separate power, ensure the independence of the judiciary and legislature, and protect citizens' rights; otherwise, democracy will not be stabilized. Since democracy is a system of government in which the citizens exercise power directly or elect representatives from among themselves to form a governing bodysuch as a parliament, institutions symbolizing adherence to democracy are essential in a democratic government to ensure that the government follows the constitution and legal laws and does not subvert to a non-democratic system. More institutionalized regimes allow for greater freedom of expression, such that political parties are a vehicle for debates on public policy, and non-partisan civic organizations allude to the promotion of democratic ideals and citizen participation. Furthermore, national political institutions provide the subject matter of comparison in terms of their powers, functions, roles and mutual relations. They adequately address new issues created such as social, economic and political challenges; they also characterize decision-making at all levels in a way that is effective, transparent, accountable, sensitive, inclusive, participatory and representative. Institutions really matter because they influence norms, beliefs, and actions, hence their ability to shape outcomes (Przeworski, 2004). "The influence of institutions over the conduct of politics is manifold, encompassing both the 'dignified' and the 'efficient' parts of the constitution (Vivien and Mark 2013)" ranging from state matters to the local government's daily service.

Democratization is theoretically and practically impossible without political liberalization since democratic institutions will thrive only in the context of civil liberty. For that reason, there is a tendency to conceptualize democratization as a process that is codified and guarantees state institutions such as the parliament, impartial judiciary, electoral institutions, in- 


\section{The Role of Political Institutions in Africa In Building Democratic Govern- ments}

dependent media, civil liberties etc. In this regard, democratization involves the creation and expansion of political space for multiple actors to interact, negotiate, compete and seek self-realization with set and permissible rules. It is not a uni-linear process but one that is relative, incremental and variegated. It is not a one start event but a continuous process through which democracy is involved (Nordlund and Salih, 2007). Thus, although, democratization has various dimensions; trajectories; and distinctions, the end goal is the same, which is to establish a democratic order. Bangura, Bratton and Van de Walle succinctly characterize democratization as follows:

Democratization involves the construction of participatory and competitive political institutions. The process of democratization begins with political challenges to authoritarian regime, advances through the political struggles over liberalization and requires the installation of freely elected government. It concludes only when democratic rules become firmly institutionalized as well as valued by political actors at large (Michael and Nicholas, 1997).

In addition, the first requirement of minimal democracies is the existence of institutions and procedures, through which citizens can express effective preferences about alternative policies at the national level, and if there are institutionalized constraints on the exercise of power by the executive. Having separate institutions helps to segregate the tasks which make the implementation and regulation of laws easier and monitoring to become hassle-free with each institution doing their job correctly. The absence of checks and balances can quickly transform the attempt to build democracy into tyranny, as in case of most African countries. Here it is our particular contention that vestigial authoritarian institutions are a threat to democratic transitions if revolutionary actors do not sufficiently delegitimize them, because the institutional composition and validation can dramatically affect the implications for a democratic transition.

\section{Conclusion}

Scholars and policymakers have widely documented institutional weakness as a notable problem in Africa. The dysfunction of institutions had become a major problem mainly because of the absence of any national state institutions before the transition began. Similarly, throughout 
Idris Mahmoud Idris, Elfatih Abdullahi Abdelsalam, Abdulhamid Mohamed 448

Ali Zaroum

sub-Saharan Africa, states exist but are mostly incoherent, nonfunctional, and instable. Many African countries that sought more democratic forms of governance were burdened by a long history of consistently poor performance by state institutions. The continued rule of the same individual for decades, often accompanied by a sham election to validate their continuation in power, has further corroded national state institutions. Therefore, many scholars argue that "To try to build a democracy on the institutions inherited from a former colonial power, from a fallen authoritarian regime or even some previous semi-democratic regime is often deemed to be doomed to become an unsuccessful attempt (Swedish International Development Cooperation Agency (Sida), 2002)." A key characteristic of liberation movements that won independence through an armed struggle is that they controlled armies, police and justice institutions. It was these institutions that often became institutions of the state, hence, the distinction between institutions of the party, the government and the state disappeared. In these countries, democratization with public institutions independent of direct control by the ruling party is an outcome that is yet to materialize. In such countries, the new political actors also have a considerable opportunity for action due to the non-existence of rules, especially in the newly formed political system. An increasing number of democracy activists and academics have concluded that the existence of effective state institutions is a prerequisite for the processes of democratization and democratic consolidation (Michael and Nicholas, 1997), a process of democracy-building will never complete unless democracy is sustained by institutional mechanisms and initiatives.

Thereby, in order to play a role in establishing and sustaining democratic values, governance-related institutions such as the civil service, electoral systems, the media, trade unions, legal courts, human rights legislation and other local institutions needs to be installed. Likewise, particular attention should be paid to the preservation of democratic institutions because the failure of institutions to enforce policies and ensure progress has been an impediment to democratic transition.

\section{BIBLIOGRAPHY}

Acemoglu, A., and J. Robinson (2012) Why Nations Fail: The Origins of Power, Prosperity and Poverty, London: Profile Books.

Adetiba, T. C. (2018) Institutionalizing democracy, Global Encyclopaedia 
449 The Role of Political Institutions in Africa In Building Democratic Governments

of Public, Administration Public Policy and Governance, Springer, Cham.

Bertelsmann Transformation Index (BTI) https://www.bti-project.org/en/home.html

Carey, John M (2000) Parchment, Equilibria, and Institutions, Comparative Political Studies. V33- N.6/7

Cheeseman, N. (2020) A Changing of the Guards or A Change of Systems? BTI Regional Report Sub-Saharan Africa, Bertelsmann Stiftung.

Cheeseman, N. (2015) Democracy in Africa: Successes, failures, and the struggle for political reform (Vol. 9) Cambridge University Press

Dahl, R.A. (1989) Democracy and Its Critics, Yale University Press, New Haven.

Dahl, R. A. (2015) On Democracy: Second Edition, Yale University Press.

Decalo, Samuel,(1992) The Process, Prospects and Constraints of Democratization in Africa, African Affairs, Vol. 91, No. 362

Fukuyama, F. (2011) The Origins of Political Order: From Prehuman Times to the French Revolution, New York: Farrar, Strauss and Giroux

Fukuyama, F. (2014) Political Order and Political Decay: From the Industrial Revolution to the Globalisation of Democracy. London: Profile Books.

Freedom House, https://freedomhouse.org/countries/freedomworld/scores

Huntington, S. (2006) political order in changing societies, Yale University Press

Huntington, S. (1991) Democracy's Third Wave, Journal of Democracy Vol.2. No.2 PP.12-34

Huntington S. (1968) Political Order in Changing Societies, New Haven, Yale University Press.

James D. Wright edt. (2015) International Encyclopedia of the Social \& Behavioral Sciences, second Edition, US Elsevier. 
Idris Mahmoud Idris, Elfatih Abdullahi Abdelsalam, Abdulhamid Mohamed 450 Ali Zaroum

Mainwaring, S. and Scully, T. (1995); Building Democratic Institutions: Party Systems in Latin America, Stanford University Press

Merkel, W. (1996) Institutions and Democratic Consolidation in EastCentral Europe, the Juan March Institute Papers, Madrid, No. 86.

Michael Bratton and Nicholas van de Walle (1997) Democratic experiments in Africa, Cambridge University Press.

Nordlund, Per and Salih, Mohamed Abdel Rahim M (2007) political parties in Africa: challenges for sustained multiparty democracy, Stockholm : International IDEA

North, Douglass (1994) Economic performance through time, The American economic review, 84 N.3 pp. 359-368.

Peter Anyang Nyong'o, ed. (1987) popular struggles for democracy in Africa, London and New Jersey, Zed Books Ltd

Przeworski, Adam, et al. (1995) sustainable democracy, Cambridge University Press.

Przeworski Adam (2004) Institutions Matter? Government and Opposition, Vol. 39; Iss. 4, pp 527-541

Renske Doorenspleet (2004) The structural context of recent transitions to democracy, European Journal of Political Research 43: 309-335

Sartori, G. ed. (1994) Comparative Constitutional Engineering: An Inquiry into Structures, Incentives and Outcomes, New York University Press.

Schumpeter, J.A. (1943) Capitalism, socialism and democracy, Taylor \& Francis e-Library, 2003

Richard Joseph (1997) Democratization in Africa after 1989: Comparative and Theoretical Perspectives, Comparative Politics, Vol. 29, No. 3, pp. $363-382$

Swedish International Development Cooperation Agency (Sida) (2002) The Political Institutions: Parties, Elections and Parliaments, www.sida.se

The World Bank (2002) Building Institutions for Markets, World Development Report 2002, Oxford University Press. 
451 The Role of Political Institutions in Africa In Building Democratic Governments

Thomas,Carothers (2002) The End of the Transition Paradigm, Journal of democracy, 13(1), 5-21.

Tripp, A.M. (2001) Women's Movements and Challenges to Neopatrimonial Rule: Preliminary Observations from Africa, Development and Change, Vol. 21, Pp. 33-54

Vivien Lowndes and Mark Roberts (2013) Why Institutions Matter the New Institutionalism in Political Science, UK, Palgrave Macmillan. 